\title{
The Influence of the Independent Board of Commissioners on Financial Performance
}

\author{
Meiryani, Sani Muhammad Isa
}

\begin{abstract}
Financial performance is a view of a capable economic outcome achieved by the company at a certain time through activities company. Financial problems are one of the most vital problems for companies in business development in all companies. The company's ability to generate profits is the key to the company's success to be said to have good company performance. This study explains the phenomena of the quality of financial reporting and good corporate governance mechanisms, namely the composition of the independent board of commissioners. The total population of big cap companies is fifty companies and those who meet the criteria for the sample are thirty-two companies. This type of research is causal research. The method of analysis in this study uses path analysis to examine the causal relationships between exogenous and endogenous variables. The results showed that the composition of the independent commission's board of influence on financial statements.
\end{abstract}

Keywords: Proportion of Independent Commissioners, Audit Committees, Financial Performance

\section{INTRODUCTION}

The company has the main goal of maximizing the company's financial performance or maximizing shareholder wealth (value maximization or stockholder wealth maximization). To achieve this goal, shareholders submit management of the company to professionals called managers. The appointment of managers by shareholders to manage the company in reality often faces problems because the company's goals clash with the manager's personal goals. With the authority they have, managers can act in their own favor and sacrifice the interests of shareholders. This may occur due to differences in information held by the two. Some widely known cases of accounting reporting scandals include Enron, Merck, World Com and the majority of other companies in the United States (Cornett et.al 2006). Some cases such as cases that occurred in Indonesia, such as PT. Lippo Tbk and PT. Kimia Farma Tbk also involves financial reporting (financial reporting) which originated from manipulation (Boediono, 2005). Some cases that occurred in

Revised Manuscript Received on December 30, 2019.

* Correspondence Author

Meiryani*, Accounting Department, Faculty of Economics and Communication, Bina Nusantara University, Jakarta, Indonesia 11480 meiryani@binus.edu

Sani Muhammad Isa, Computer Science Departement, BINUS Graduate Program-Master of Computer Science, Bina Nusantara University, Jakarta 11480 Indonesia

sani.m.isa@binus.ac.id

(c) The Authors. Published by Blue Eyes Intelligence Engineering and Sciences Publication (BEIESP). This is an open access article under the CC BY-NC-ND license (http://creativecommons.org/licenses/by-nc-nd/4.0/)
Indonesia, such as PT. Lippo Tbk and PT. Kimia Farma Tbk is overstated, namely an inflation of annual net profit of Rp. 32,668 billion (financial statements which should have been Rp. 99.594 billion written Rp. 132 billion) involving Public Accounting Firms (KAP) who are the company's auditors (Tjager et al., 2003). In this case there was a violation of the principles of accurate disclosure and transparency, which consequently was very detrimental to investors, because overstated earnings had been used as the basis of transactions by investors for business involving financial reporting that began from being detected by manipulation (Gideon, 2005). This phenomenon shows that the occurrence of financial scandals is the failure of financial statements to meet the information needs of report users. One reason for the scandal was the lack of supervision by independent commissioners, audit committees and outside supervision by institutional investors. Evidence shows the weak oversight of independent boards of commissioners, audit committees and outside investors leads to deficiencies in decision making in companies and corporate actions (Alijoyo and Zaini, 2004). The company will likely use accounting information to assess manager's performance. Another possibility is that accounting information is used in conjunction with non-accounting information to assess the manager's performance. The manager's performance is manifested in various activities achieving the company's goals. And because each activity requires resources, management performance will be reflected in the use of resources to achieve company goals. Besides that accounting information is an objective basis and not subjective as a basis for evaluating manager performance. In relation to performance, financial statements are often used as a basis for evaluating company performance. Measurement of the company's financial performance is needed to determine success in achieving company goals, namely maximizing shareholder value. Financial statements (financial statements) are the main tool for companies to convey company information about the responsibilities of management (Schipper and Vincent, 2003). Submission of information through the financial statements needs to be done to meet the needs of external and internal parties who lack the authority to obtain the information they need from direct sources of the company. Financial statements are one source of information that must be formally published as a means of management's accountability towards the management of owner's resources. Financial statements prepared by companies are recognized by investors, creditors, suppliers, labor organizations, stock exchanges and financial analysts as important sources of information about the existence of the company's economic resources that are expected to be useful for decision making, and this information is also expected to be a guideline for shareholders and potential investors to determine their

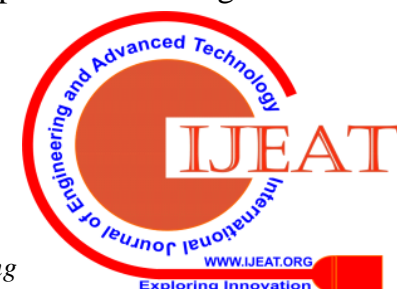


investment interests in the issuer's shares.

One type of financial statement that measures the success of a company's operations for a certain period is the income statement. Profit is used as a tool to measure the performance of company management during a certain period which is generally a concern of certain parties, especially in estimating the performance of management's responsibility in managing the resources entrusted to them. Profit is a major element in financial statements and is very important for those who use it because it has predictive value. Earnings information is used to assess potential changes in economic resources that may be returned in the future, generate cash flow from existing resources, and to formulate considerations about the effectiveness of the company in utilizing additional resources. For shareholders and / or investors, profit means an increase in the economic value (wealth) that will be received through dividends. Profit is also used as a tool to measure the performance of company management during a certain period which is generally of particular interest to certain parties, especially in assessing the performance of management's responsibility in managing the resources entrusted to them, and can be used to estimate the company's prospects in the future. the profit figures generated in the income statement are often influenced by the accounting method used, so high profits may not necessarily reflect large cash flows.

However, the profit figures generated in the income statement are often influenced by the accounting methods used, so high profits may not necessarily reflect large cash flows. In this case cash flow has more value to guarantee the company's performance in the future. Cash flow shows the results of operations for which funds have been received by the company and are burdened with cash expenses that have actually been incurred by the company (Pradhono, 2004). Cash Flow Return on Assets (CFROA) is a measurement of company performance that shows the ability of company assets to generate operating profit. CFROA is more focused on measuring the company's current performance and CFROA is not bound by stock prices (Cornett et al, 2006).

In order to produce quality financial reports within a company, internal control and external control are needed, which include: First, through ownership of shares by institutional investors, those who can monitor agents with large holdings, so that managers' motivation to manage earnings is reduced. Institutional ownership is the ownership of shares of companies which are majority owned by institutions or institutions (insurance companies, banks, investment companies, asset management and ownership of other institutions). Institutional ownership is the largest shareholder so it is a means to monitor management so that it can produce quality financial reports. (Djakman and Machmud, 2008).

Institutional ownership is usually majority, so this group can monitor the manager's performance optimally. As a result, managers relatively limit their share ownership, whereas low institutional ownership causes the control mechanism of external parties to be weak so that managers are more free to take decisions or are involved in share ownership. The existence of ownership by institutional investors such as insurance companies, banks, investment companies, and ownership of other institutions will encourage increased optimal oversight of management performance, because share ownership represents a source of power that can be used to support or vice versa on the existence of management.
Faisal (2005) indicates that institutional ownership has not been effective as a tool to monitor management in increasing company value. This is contrary to the results of Cornett et. Al (2006). Second, through the role of monitoring by the board of directors (board of directors) that the higher the representation of the board in the manager's involvement in earnings management will be lower. The influence of the size of the board of commissioners on company performance has mixed results. The large number of personnel on the board of commissioners can result in poor performance of the company (Yermack 1996, Eisenberg, Sundgren, and Wells 1998, and Jensen 1993). Several other researchers found that the high proportion of the outside board was positively related to company performance (Yermack, 1996; Daily \& Dalton, 1993), not a factor of company performance (Kesner \& Johnson, 1990) and negatively related to performance (Baysinger, Kosnik \& Truck , 1991; Goodstein \& Boeker, 1991). Third, through the role of the audit committee responsible for overseeing financial statements, overseeing external audits and observing the internal control system so that it can reduce the opportunistic nature of management that performs earnings management by overseeing financial statements.

\section{THEORETICAL FRAMEWORK}

The results of Baesley's research (1996) suggest that the inclusion of a board of commissioners from outside the company increases the effectiveness of the board in overseeing management to prevent financial statement fraud. Beasley (1996) states that the inclusion of a board of commissioners from outside the company increases the effectiveness of the board in overseeing management to prevent fraudulent financial statements. Dechow, Patricia, Sloan and Sweeney (1996), Klein (2002), Peasnell, Pope and Young (2001), Chtourou et al. (2001), Midiastuti and Mackfudz (2003), and Xie, Biao, Wallace and Peter (2003) conclude that companies that have a proportion of the board of commissioners from outside the company or outside directors can influence performance. Thus, if outside commissioners increase supervision measures, this will also be related to lower discretionary accruals so that financial reports are reported to be of higher quality (Cornett et al., 2006). Klein (2002) found that companies that have a proportion of the board of commissioners from outside the company or outside directors can influence performance. Thus, if outside commissioners increase supervision measures, this will be related to the lower use of discretionary accruals. Based on a theoretical review, a review of previous research and a framework of thought that has been described above, the hypotheses proposed in this study are as follows: $\mathrm{H} 1$ : The proportion of independent commissioners influences financial performance.

\section{RESEARCH METHODOLOGY}

The data analysis tool used in this study is path analysis to determine the effect of exogenous and endogenous variables based on the model structure. 
Before testing the hypothesis, the assumption test was previously carried out namely the Normality and Linearity Test, the Autocorrelation Test and the Heteroscedasticity Test.

1. Descriptive Statistics Test

This analysis calculates the minimum, maximum, mean, standard deviation, and other information of the variable institutional ownership, the proportion of independent commissioners, audit committees, earnings management and financial performance.

2. Classical Assumption Test

a. Normality test

Normality testing is testing about normality of data distribution. The use of normality test is because in the parametric statistical analysis, the assumption that must be owned by the data is that the data is normally distributed ie the data will follow the form of a normal distribution.

b. Linearity Test

This assumption states that the relationship between the independent variable and the dependent variable must be linear. Two variables are said to have a linear relationship if the significance (deviation from linearity) is more than 0.05 or 5\% (Priyatno, 2008).

Autocorrelation Test

The term autocorrelation is defined as the correlation between observational members sorted according to time (such as periodic series data) or space (such as cross-sectoral data) (Gujarati, 2006). In the context of regression, the classical linear regression model assumes that such correlations are not present in disturbance. To be able to detect the presence of autocorrelation the Durbin Watson test was used.The $\mathrm{dL}$ and $\mathrm{dU}$ values are searched using the Durbin-Watson Table.

Heteroscedasticity Test

An important assumption of the classical linear regression model is that the disturbance that arises in the regression is homoscedasticity, ie all the disturbances have the same variance (Gujarati, 2006). One way to test whether heteroscedasticity occurs is by the Glejser Test. This Glejser Test is carried out by regressing the absolute value of the residual.

To test the hypothesis used path analysis using the regression method implemented using the SPSS for Windows version 17.0 statistical computer program.

\section{RESULT AND DISCUSSION}

Result

Descriptive statistics

The sample selection process in this study produced 128 company observations for the study periods of 2008, 2009, 2010 and 2011. To obtain a general picture of the research sample data, Table 4.1 provides a statistical overview of the overall sample data.

\section{Tabel 1. Descriptive statistics}

\begin{tabular}{|l|l|l|l|l|}
\hline & Minimum & Maximum & Mean & Standard Deviation \\
\hline $\begin{array}{l}\text { The proportion } \\
\text { of independent } \\
\text { boards of } \\
\text { commissioners }\end{array}$ & 3.40 & 4.32 & 3.80 & 0.23 \\
\hline $\begin{array}{l}\text { Financial } \\
\text { Performance }\end{array}$ & 2.96 & 4.58 & 3.67 & 0.40 \\
\hline
\end{tabular}

Source: processed data

From Table 4.1 above, it can be explained that the proportion of the independent board of commissioners variable which was processed from the annual financial statements dated December 31, 2008, 2009, 2010 and 2011 from 128 observations had an average of 3.80 with a standard deviation of 0.23 . The minimum value of the proportion of the independent board of commissioners is 3.40 and the maximum value of the proportion of the independent board of commissioners is 4.32. Financial Performance variable which is processed from the annual financial statements dated December 31, 2008, 2009, 2010 and 2011 from 128 observations has an average of 3.67 with a standard deviation of 0.40. Minimum Financial Performance is 2.96 and the maximum value is Financial Performance is 4.58.

Classic assumption testBefore testing the hypothesis using the Path Coefficient testing also tests the deviation of classical assumptions. This test is performed to test the validity of the results of the Path Analysis analysis. The tests conducted are normality test, linearity test, autocorrelation test, and heteroscedasticity test.

Normality testThe results of Skewness and Kurtosis in table 4.2 give a normal distribution pattern. From the quotient of the skewness value divided by the standard error skewness of 0.08773 and the value of kurtosis divided by the standard error of kurtosis of -1.65763 . From the results, the Skewness and kurtosis values meet the normality assumption because the Skewness values are between -2 to +2 .

\section{Table 2. Normality of data with the dependent variable} Financial Performance.

\section{Descriptive Statistics}

\begin{tabular}{|l|l|l|l|l|l|}
\hline & N & \multicolumn{2}{|l|}{ Skewness } & \multicolumn{2}{l|}{ Kurtosis } \\
\cline { 2 - 6 } & Statistic & Statistic & Std. Error & Statistic & Std. Error \\
\hline $\begin{array}{l}\text { Unstandardized } \\
\text { Residual } \\
\text { Valid N (listwise) }\end{array}$ & 128 & .722 & .214 & .356 & .425 \\
\hline
\end{tabular}

Source: processed data

Linearity Test

Two variables are said to have a linear relationship if the significance (Linearity) is less than 0.05 or $5 \%$ (Priyatno, 2008). The linearity table in table 4.3 shows that the variable of institutional ownership, the proportion of independent board of commissioners and audit committee is linear, as evidenced by the significance value (linearity) of less than 0.05 or $5 \%$, each of which is $0,000,0.001$ and 0.051 .

Table 3. Normality of data with the dependent variable Financial Performance.

ANOVA Table

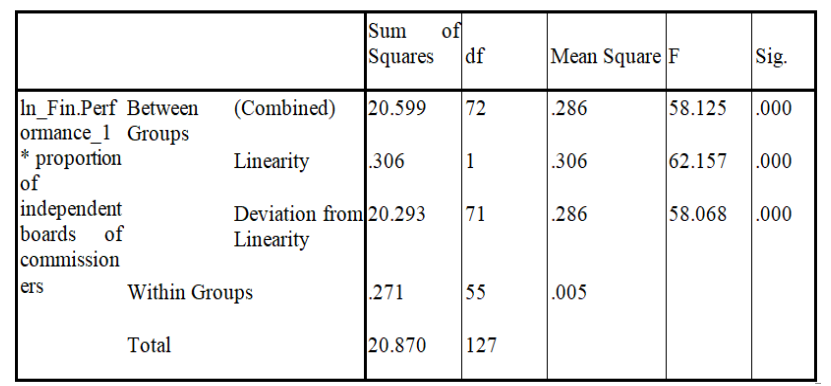


Autocorrelation Test

To be able to detect the presence of autocorrelation the Durbin Watson test was used. The $\mathrm{dL}$ and $\mathrm{dU}$ values are searched using the Durbin-Watson Table. The detection of autocorrelation in this study used the Durbin Watson test mechanism is as follows (Andryan, 2010):

\section{Table 4.4 Durbin-Watson Autocorrelation Test}

\begin{tabular}{|l|l|l|l|l|l|l|}
\hline Dependent & $\mathrm{N}$ & $\mathrm{k}$ & \multicolumn{2}{|l|}{ DW Table } & Durbin & Decision \\
\cline { 4 - 6 } Variable & & & $\mathrm{dl}$ & $\mathrm{dll}$ & Watson & \\
\hline Fin.Performance & 128 & 4 & 1.6475 & 1.7762 & 0.420 & $\begin{array}{l}\text { A positive } \\
\text { aotocorrelation has } \\
\text { occurred }\end{array}$ \\
\hline
\end{tabular}

From the regression results conducted using the SPSS 17.0 program, the results for the earnings management regression variable as the dependent variable obtained DW value of 0.420 are between the values of 0 and $\mathrm{dl}$, then it can be said to have a positive autocorrelation.

Heteroscedasticity Test

One way to test whether heteroscedasticity occurs is by the Glejser Test. This Glejser Test is carried out by regressing the absolute value of the residual. If the significance is less than 0.05 or $5 \%$, a heteroscedasticity problem occurs.

Table 4.5

Testing heteroscedasticity assumptions with the Glejser Financial Performance Test as the dependent variable

\section{Coefficients $^{\mathrm{a}}$}

\begin{tabular}{|c|c|c|c|c|c|c|}
\hline & \multirow[b]{2}{*}{ Model } & \multicolumn{2}{|c|}{$\begin{array}{l}\text { Unstandardized } \\
\text { Coefficients }\end{array}$} & \multirow{2}{*}{$\begin{array}{c}\text { Standardized } \\
\text { Coefficients } \\
\text { Beta }\end{array}$} & \multirow[b]{2}{*}{$\mathrm{t}$} & \multirow[b]{2}{*}{ Sig. } \\
\hline & & B & Std. Error & & & \\
\hline \multirow[t]{2}{*}{1} & (Constant) & .290 & .475 & & .610 & .543 \\
\hline & $\begin{array}{l}\text { Independent_b } \\
\text { oards_commiss } \\
\text { ioners }\end{array}$ & .161 & .073 & .189 & 2.195 & .030 \\
\hline
\end{tabular}

Judging from the significance of each in table 4.5 above is $0.030,0.002,0.119$, the institutional ownership variable and the variable proportion of the independent board of commissioners occur heteroscedasticity problems seen from the probability of significance below the confidence level of 0.05 (5\%) that is 0.030 and 0.002 but the committee variable The audit shows that there is no heteroscedasticity problem, which is seen from the significance value above 0.05 , which is 0.119 , which means the regression model does not support heteroscedasticity.

Data Analysis Results

The results of the analysis of research data based on the first substructure and the second substructure can be shown in Table 4.10.

Hypothesis Testing Analysis Results

Influence of the variable proportion of independent commissioners on financial performance

The results of the analysis as presented in table 4.1, show the effect of the variable proportion of the independent board of commissioners (X2) on financial performance (Y) with the path coefficient value obtained by -0.211 . Statistically it can be stated that the proportion of independent board of directors has a significant effect on financial performance, as evidenced by the significance value of $t$ smaller than 0.05 which is equal to 0.022 . The magnitude of the direct effect of the variable independent proportion of the board of commissioners on financial performance $(\mathrm{Y})$ is $(-0.211 \mathrm{x}$ $-0.211 \times 100)=4.45 \%$

\section{a. DISCUSSION}

The effect of the proportion of independent commissioners on financial performance

The analysis shows that the direct effect of the proportion of the independent board of commissioners on financial performance is a significant negative that is -0.211 or $4.45 \%$. This proves the proportion of the independent board of commissioners is able to explain the responsive strength of earnings or financial performance, the composition of the board of commissioners is considered to have an effective ability to carry out the supervisory function. The findings of this study are consistent with the results of previous studies conducted by Andersen (2003), that the composition of the board of commissioners influences financial performance.

\section{CONCLUSION}

From the phenomena, problem formulation, previous studies, hypotheses From the results of testing and data analysis in the previous chapter, the following conclusions can be drawn: the proportion of independent commissioners has a strong influence on financial performance. Statistically the effect of the proportion of independent commissioners on financial performance is significant. This indicates that the number of independent commissioners in controlling the process of preparing financial statements is strongly responded by the market.

\section{REFERENCES}

1. Beasley, Mark S. (1996). An Empirical Analysis of the Relationship Between the Board of Directors Composition and Financial Statement Fraud. The Accounting Review, Vol. 17. No.4, October, p. 443-465.

2. Boediono, Gideon, 2005. Earnings Quality: Study of the Effects of Corporate Governance Mechanisms and the Impact of Earnings Management by Using Path Analysis: National Symposium on Accounting VIII. IAI, 2005.

3. Bryshaw, R.E and Ahmed Eldin. (1998). The Smoothing Hypothesis and The Role of Exchange Differences. Journal of Business, Finance and Accouncing, p. 621-633.

4. Cornett M.M, J. Marcuss, Saunders and tehranian H. 2006). Earnings Management, Corporate Governance, and True Financial Performance. http://papers.ssrn.com/

5. Chtourou, SM., Jean Bedard. And Lucie Courteau. (2001). Corporate Governance and Earniings Management. Working Paper. Universite Laval, Quebec City, Canada. April.

6. Davidson III, Wallace N., Biao Xie, and Weihong Xu. 2004. Market Reaction to Voluntary Announcements of Audit Committee Appointments: The Effects of Financial Expertise. Journal of Accounting and Public Policy Volume 23 July-August: 279-293.

7. Dechow, Patricia M., R.G. Sloan p. A.P. Sweeney. (1996). Causes And Consequences Of Manipulaton Earnings: An Analysis Of Firms Subject To Enforcement Actions By The SEC. Contemporary Accounting Research 13, 1-36

8. Deni Darmawati, Khomsiyah and Rika Hold Rahayu. (2004) Relationship of Corporate Governance and Company Performance. National Simponium Accounting VII, IAI, 2004.

9. Fama E.F. and M.C.Jensen. (1983). Separation of Ownership and Control. Journal of Law and Economics, Vol.26. p.301-325.

10. Grielsen, Gorm., Jeffrey D. Gramlich and Thomas Plenborg. (1997) Managerial Ownership, Information Content of Earnings, and Discretionary Accruals in a Non-US Setting. Journal of Business Finance and Accounting, Vol. 29.No.7 \& 8. September / October, p. 967-988. 
11. Halim, Julia, Carmel Meiden and Rudolf Lumban Tobing. 2005. Effect of Earnings Management on the Level of Disclosure of Financial Statements in Manufacturing Companies Included in the LQ-45 Index. Articles of Accounting National Symposium (SNA) VIII. Solo.

12. Haris Wibisono. (2004). The Effect of Earnings Management on Performance Around SEO. Thesis S2. Master of Science in Accounting UNDIP.

13. Hastuti, Theresia Dwi. 2005. The relationship between good corporate governance and the Ownership Structure and Financial Performance. Articles of Accounting National Symposium (SNA) VIII, Solo.

14. Jensen, M.C. (1993). The Modern Industrial revolution, Exit, and the Failure of Internal Control System. Journal of Finance, Vol. 48. July, p. 831-880.

15. Meiryani \& Lusianah. 2018. The Influence of Business Process on Accounting Information System Quality. Pertanika Journal of Social Sciences and Humanities. 26, pp. 209-218.

16. Meiryani. 2018. The Factors That Affect the Quality of Accounting Information System Empirical Testing in the State-Owned Enterprises. Journal of Theoretical and Applied Information Technology. $15^{\text {th }}$ April 2018, Vol. 96. No. 7.

17. Meiryani, Azhar Susanto and Dezie Leonarda Warganegara. 2019. The Issues influencing of environmental accounting information systems : An Empirical investigation of SMEs in Indonesia. International Journal of Energy Economics and Policy. 9 (1) : 282-290.

18. Midiastuty, Pratana P., and Mas'ud Machfoedz. 2003. Relationship Analysis of Corporate Governance Mechanisms and Indications of Earnings Management. Article of the National Symposium on Accounting (SNA) VI, Surabaya.

19. Pradhono and Yulius Jogi Cristiawan. (2004). Effects of economic Value Added, Residual Income, Earnings and Operating Cash Flow on Returns Received by Shareholders (Study of manufacturing companies listed on the Indonesia Stock Exchange). Journal of Accounting and Finance Vol. 6, No. 2, November. Pp. 140-166.

20. Theresia Dwi Hasturi. (2005). Relationship between Good Corporate Governance and Ownership Structure and Financial Performance (Case Study of Companies listed on the Jakarta Stock Exchange) Accounting National Symposium VIII, IAI, 2005.

21. Ujiyantho, Arief Muh (2007). GCG Mechanism, Earnings Management and Financial Performance (Study in the Go Public Company Manufacturing Sector). National Simponium Accounting X, Makassar Hasanuddin University.

22. Veronica, Sylvia and Siddharta Utama. 2005. The Effect of Ownership Structure, Company Size, and Corporate Governance Practices on Earnings Management. Articles of Accounting National Symposium (SNA) VIII, IAI, Solo.

23. Warfield, Terry D., J.J. Wild, and K.L. Wild (1995). Managerial Ownership, Accounting Choices, and Information of Earnings. Journal of Accounting and Economics 20, p. 61-91.

24. Wedari, Linda Kusumaning. 2004. Analysis of the Impact of the Proportion of the Board of Commissioners and the Existence of the Audit Committee on Earnings Management Activities. Articles of Accounting National Symposium VII (SNA) VII, IAI, Denpasar.

25. Yermack, D., 1996. Higher Market Valuation of Companies With A Small Board of Directors. Journal of Financial economics 40, 185-211.

\section{AUTHORS PROFILE}

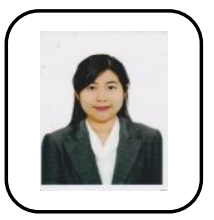

Dr. Meiryani., SE., Ak., MM., M.Ak., CA is a lecture of accounting information systems and management information systems. Born in Pontianak in 1988. Completed S1 in UNTAN Accounting major in 2010, Masters in Management completed in Tanjungpura in 2012, Masters in Accounting completed in 2012 at STIE YAI in Jakarta Pusat, completed accounting profession education (PPAk) in 2013 UNTAN. Doctoral education was completed in 2016 at the UNPAD with Judicium cumlaude. Aside being a lecturer at Binus University, she is also active as a book writer, researcher, consultant in developing accounting/management information systems. Some writings are spread in various indexed international journals and reputable international journals (Scopus). Other books that have been written are Analysis and Design System (2015), Management Information Systems (2015) and Fundamentals of Management (2016), Introduction to Accounting (2018), Accounting Information System (2019). The author can be contacted via: meiryanibongjunshien@gmail.com.

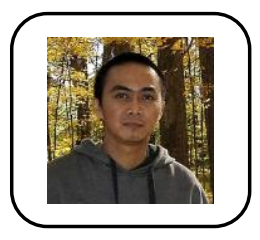

Dr. Sani Muhammad Isa.,S.Si.,M.Kom is lecturer of lecturer \& researcher at Master of Information Technology, Bina Nusantara University, Indonesia He research interests are signal/image processing, biomedical engineering, data mining, and remote sensing. 